\title{
AYTMATOV ANLATILARINDA ÇAĞDAŞ MANAS RUHU VE YANSIMALARI
}

\begin{abstract}
Ahmet SARIGÜL
Öz: Manas Destanı ve Manas ruhunun millî-manevî bütünlüğü sağlayıcıllı̆̆ ve zengin bir millî hafıza ürünü oluşu birçok araştırmacı ve edebiyat otoritesinin dikkatini üzerine çekmiştir. Ancak bir yazar kimliğiyle bu eseri değerlendiren ve eserlerinde yer vermek suretiyle hem destanın evrensel boyutta tanınmasına hem de kendi eserlerinin bu destan vesilesiyle evrensel boyuta taşınmasına en büyük katkıyı sağlayan Cengiz Aytmatov olmuştur. Manas Destanı'nı kendisi açısından tam zamanında keşfeden ve sanatı için sanatsal yönünü değerlendirmesini bilen Aytmatov, destanı tanıma, tanıtma ve yararlanma konularında birlikte yola çıktığı ve aynı kulvarı paylaştığı çağdaşlarının önüne geçerek mahalliden millîye ve oradan da evrensele açılan kapıyı aralayabilmiştir. Kendine özgü üslup ve orijinalitesi nedeniyle Aytmatov'un Manas Destanı'na dönük yüzü ve eserlerinde yer veriş biçimi çağdaşlarına nazaran tamamen farklı bir çizgide seyretmiştir. Söz konusu destanın ortak Türk kültür ve medeniyetinin bir değeri olması ve Aytmatov'un bu değeri global anlamda dünyaya duyurması onun ikinci bir Manas/çağdaş Manas olarak anılmasına da neden olmuştur. Bu karşıllıklı etkileşim, destanın ve Manas ruhunun Aytmatov anlatılarına ayrı bir sanatsal renk, ahenk, ritim, ışık ve manevî güç katmasına vesile olmuştur. Bu ortak kültür dinamikleriyle yoğrulan yazar, aynı zamanda Türk dünyasının ortak sesi olma misyonunu da üstlenmiştir. Aytmatov, Kırgız halkının tarihi süreç içerisinde derlediği ve kendi değerleriyle renklendirdiği kültür, medeniyet, örf-adet, gelenek-görenek, yaşam felsefesi ve görüşlerinin bir bütününü oluşturan, kısacası ortak Türk dünyasının kültürel kodlarıyla millî hafızasını özünde barındıran Manas Destanı aracıllğııla kendi görüş ve düşüncelerini evrensel boyuta taşıma olanağını da bulmuştur. Çünkü Aytmatov'un kahramanları "Manas'ın" ruhundan ateş almış, onun ruhuyla özdeşleşmiş güçlü karakterlerdir.
\end{abstract}

Anahtar Kelimeler: Manas Destanı, Aytmatov, Millî Hafıza, Evrensel, Türk Dünyas1.

\section{MANAS SPIRIT AND CONTEMPORARY REFLECTIONS ON AITMATOV NARRATIVES}

Abstract: Manas epic and Manas that is providing the national-spiritual integrity and a rich product consisting of national memory has attracted the attention of many researchers and literary authority. However, Chingiz Aitmatov was a writer who made the biggest contribution to the recognition of the identity and the universal

Geliș tarihi: 09. 10. 2017

Kabul tarihi: 03. 01. 2018

*. Doktor. 
dimension of epics by giving in to evaluate this work and works well to move to a uni versal dimension through this saga of his works. Manas epic is discovering the right time for himself and knows the assessment of the artistic direction for the arts of Aitmatov, recognition of the saga was on his way with the introduction and utilization issues from national to local surpassing his contemporaries shared the same lane and could be opened from there to the universal gateway. Due to the unique style and originality Aitmatov's Manas epic shopping format on its side facing the ground and remained in a completely different line of work than their contemporaries. It is said to be a common value of the Turkish culture and civilization and epic, announce to the world the sense that the value of its second global Manas / has led to the modern-called Manas. These interactions, epic narratives Aitmatov and a separate artistic color to the spirit of Manas, harmony, rhythm, has been instrumental in adding light and spiritual power. This common culture blended with dynamic writer and also has undertaken the mission to be the collective voice of the Turkish world. Aitmatov, as they say in the process is the history of the Kyrgyz people and culture colored by their own values, culture, customs, traditions, constitute a totality of life philosophy and vision, short joint Turkish core of the national memory of the cultural codes and the world hosting the Manas universal own opinions and thoughts through Epic size has been found in the transport facilities because Aitmatov's heroes "Manas" has ignited the spirit, strong character are identified with his spirit. world.

Key Words: Manas epic, Aitmatov, National Memory, Universal, the Turkish

\section{Destan Üzerine}

Destan (داستان),milletlerin hayatında büyük yankılar uyandırmış tarihî, toplumsal (savaş, göç, istilâ gibi) veya doğal (yangın, salgın hastalık, sel, deprem gibi) olayların anlatıldığı, hayal unsurlarıyla süslenmiş uzun manzum eserlerdir. Destanlar; Araplarda "esatir. ", Batı'da "myth" olarak adlandırılır.

Zeki Velidi Togan; "Destanların milletin yüksek millî duygularını aksettiren halk edebiyatı eserleri olduğunu, tamamıyla veya az çok tarihe dayanan bir ideal âlemi yansıtır. " demektedir. (Geyikoğlu, 2001: 201-207)

Destanlar üzerine yoğunlaşmış ve daha önce de üzerinde durulduğu üzere Aytmatov üslubunda olduğu üzere eserlerinde destan kültürüne geniş yer vermiş olan Hüseyin Nihal Atsız da destan hakkında görüşlerini şöyle dile getirmiştir: "Bir milletin geçmişte başından geçen büyük hadiselerin halk dilinde edebi bir şekil almasıdır." (Atsız, 1997: 31)

Destan kültürü üzerine incelemelerde bulunan Mehmet Aça ise destan1;

"Milletlerin dünya görüşlerini, kâinattaki olayları yorumlayış tarzlarını, yaşadıkları tarihi ve sosyal olaylarla onların etkilerini, var 
oluşlarını ve bağımsızlıklarını sürdürebilmek için yaptıkları iç ve dış mücadelelerini, sosyal hayatla ilgili etkinliklerini, kısacası o milleti millet yapan bütün değerleri edebi bir üslup ve kahramanî bir eda ile günümüz insanlığına aktara gelen metinler." olarak tanımlar. (Aça, 2002: 5)

Destanlar, sözlü geleneğin ürünü olarak bilimsel verilerin sosyal hayata tam anlamıyla nüfuz etmemiş olduğu dönemlerde ortaya çıkmış kültürel verilerdir. Bu yönüyle destanlar ve destansı öyküler, İlk Çağlardan beri, farklı kültürlere ait örf, âdet, gelenek ve görenekleri sonraki kuşaklara aktarma misyonunu üstlenmiş kolektif ürünlerdir. Bu nedenle "Mitleri bilmek demek, nesnelerin kökenindeki sırrı ögrenmek demektir." (Eliade, 1993: 19)

Sözlü gelenek mahsulü olan destanlar en eski edebiyat türlerinden biri olup Yunanca "espos" sözcügünden türemiştir. Tarih, etnografya, folklor gibi birçok bilime kaynaklık eden destanlar; bünyesinde mitoloji, efsane, folklor ve tarihî öğeleri barındırır. Muhtevası yönüyle ele alındığında destanlar farklı zaman ve mekânlara hitap eden ve düzlemde mutlak gücü elinde bulunduran "kahraman", "bilge" kişilerin olağanüstü olaylara sahne olmuş yaşam öyküleri etrafinda meydana gelmiş, geniş hacimli ve didaktik bölümlerden oluşurlar. Bu bölümler genellikle hikâye tarzında olup içeriğinde toplumları derinden etkileyen ve savaşlar, göçler, yangınlar gibi tarihe mal olmuş önemli olayları barındırırlar. Üslup ve içeriği bakımından ele alındığında ise bu sözlü ürünler genellikle "manzum" bir yapıya sahiptirler. "Bu tür köken mitleri, kimliği koruyan bilgileri ileterek kişinin yaşamın içinde yitip gitmesini önleyen bir işlev içerir. Bunun için kişinin bu mitlerle iliş̧kiye geçmesi ve orada sakl atalar sesine kendini açması zorunludur." (Korkmaz, 2004: 78)

$\mathrm{Bu}$ içerikleri ve üslup özellikleri nedeniyle "Aytmatov, mit ve efsanelere eserlerinde sıkça yer verir. Çok iyi bir fiktif yapıyla, aynı eserde birbiriyle dikkat edildiğinde çok yakından alakall iki veya daha çok konu birlikte yürütülür. Yazarın '..... Mit ve efsaneler üzerine düşünelim. Onlar halkın felsefesi ve tarihidir. 'Şeklindeki sözleri onun masal, efsane, mit ve destanlara bakışını en iyi anlatan sözlerdir. " (Çetin, 1994: 24)

\section{Destanlarda Oluşum Süreçleri}

Destanlar oluşum süreçleri göz önüne alındığında iki ayrı başlık altında toplanırlar: 
a. Doğal (Tabii-sözlü) Destanlar: Sözlü anonim ürünlerden olan bu destanlar birtakım olağanüstü olaylar neticesinde doğmuş ve halk arasında kalıcı tesirler meydana getirerek kuşaktan kuşağa aktarılan destanlardır. Anonim olmaları nedeniyle söyleyenleri belli değildir. Yazı ve bilimsel kayıtların henüz icat edilmediği dönemler ve yaygınlaşmadığı kültürlerde fillizlenip kuşaklar arası sözlü aktarımla korunmuş, sonrasında kaleme alınmışlardır. Bu destanlar, ozan ve baksıların farklı zamanlarda seslendirdiği ağıt, nağme ve şiirsel söyleyişlerin bir bütünlüğünden meydana gelmişlerdir. Oğuz Kağan, Ergenekon ve Manas Destanları en güzel örneklerini teşkil ederler.

b. Yapma (Yapay-edebî) Destanlar: Yazı ve bilimsel verilerin artık kullanılmaya başlandığı son dönemlerde şair ve ediplerin toplum üzerinde kalıcı etkiler bırakan birtakım olayları doğal destan havasında seslendirmesi sonucu ortaya çıkmış olan destanlardır. Bu destanlar, çıkış zamanı, mekânı, kahramanları ve en önemlisi de yazarı belli olan yazılı eserlerdir. Türk edebiyatında örneklerine sıkça rastlanan bu destanların en önemli örnekleri; Nazım Hikmet'in Kuvayı Milliye ve Fazıl Hüsnü Dağlarca'nın Ü̧̧ Şehitler Destanı'dır.

\section{Destanlarda Oluşum Aşamaları}

Destanlar oluşum süreçleri doğrultusunda "doğuş", "yayılma" ve "yazılış safhası" olmak üzere üç aşamada meydana gelir:

a. Doğuş Safhası: Bu aşama toplumsal bellekte önemli izler bırakan tarihî, sosyal ve psikolojik olaylar ile bu olaylar içerisinde ön plâna çıkan efsanevî kahramanları içerir.

b. Yayılma Safhası: Bu aşamada ise, doğuş safhasında öne çıkan olay ve kahramanlıklar, kahramanlar sözlü geleneğin konusu hâline gelerek kulaktan kulağa yayılır. Bu yayılma yakın çevreden uzağa ve yakın zamandan uzak zamanlara olmak üzere genişleyen dalgalar hâlinde kuşaktan kuşağa aktarılır.

c. Derleme (yazıya geçirme) Safhası: Bu aşamada ise sözlü geleneğin yaşattığı ve aktarımını yaptığı destan, güçlü bir şair tarafından edebî usuller çerçevesinde derç edilip manzum bir yapıya kavuşturulur ve kaleme alınır. Ancak anonim özelliğe sahip olan bu eserlerin derleyeni ve kaleme alanı genellikle belli değildir.

Destanlar, temelinde tarihî olaylara dayanmakla birlikte bilimsel bir tarihsellik içermezler. Çünkü genellikle baksı ve ozanların (ya da benzerleri) "kopuz/komuz" adı verilen sazlar eşliğinde seslendirilen bu eserler toplumun sosyo-kültürel yapısı ile yaşam biçimi, dünya görüşü 
ve felsefesi hakkında ipuçları veren edebî eserlerdir. Doğal afetler, kırgınlar, kuraklık ve kıtlıklar, savaşlar, istilalar ve neticesinde yaşanan göçler toplumsal bilinçaltında önemli izdüşümleri meydana getirir ve bu eserlerin temel kaynağını oluşturur.

\section{Destanların Genel Özellikleri:}

1. Anonim-ortak bellek ürünüdürler.

2. Belli bir ulusa has kültürel özellikleri yansıtırlar.

3. Genellikle manzum bir yapıya sahip olup ozan-baksılar tarafindan seslendirilirler.

4. İstisnaları olmakla birlikte günümüze nesir biçiminde intikal etmişlerdir.

5. Tarihî, doğal ve sosyal olaylardan kaynaklanır ve beslenirler.

6. Doğal hayatı yansıtmakla birlikte olağanüstü olaylar da ön plâna çıkmaktadır.

7. Toplumsal bilinçaltına kazınmış sıra dışı olaylara dayanırlar.

8. Olağanüstü olaylar nedeniyle kahramanları olağanüstü özellikler gösterirler.

9. Tema olarak genellikle yiğitlik, aşk, dostluk, ölüm ve yurt sevgisi işlenmektedir.

10. Kahramanlıklara ve acılara dayalı coşkun söyleyişleri vardır.

\section{Manas Destanı, Oluşumu ve İçeriği}

Tarihin çeşitli devrelerinde farklı coğrafyalarda büyük devletler kurmuş olan Türkler, boylar hâlinde geniş bir coğrafyaya dağılmış ve bir dönem dağınık bir hâlde varlıklarını sürdürmüşlerdir. Kırgız Türkleri de bu boylar arasında yer alıp Orta Asya coğrafyasında (Isık-Göl çevresinde, Çuy, Talas ve Tekes Irmaklarının yukarısında Altay, Pamir, Tianşan Dağlarında) göçebe bir hayat sürmüşlerdir. Tarihî kaynaklar, tarihte ismi geçen ilk Türk boyunun Kırgızlar olduğunu kabul ederler. Kırgızlar o dönemde almış olduğu devlet adını bugüne kadar muhafaza etmeleriyle bilinir. MÖ, II. yy. Büyük Hun İmparatorluğu'na katılmış olan Kırgız Türkleri daha sonra bu imparatorluğun dağılması üzerine III. asırda "Hakas Devleti" adıyla büyük bir devlet kurmuşlardır. Kırgız Türkleri, VII. asırda Göktürklere tabi olmuşlardır. Bilge Kağan, Kül Tigin ve Tonyukuk Kitabelerinde Kırgız Türkleri üzerine yapılan seferlerin sözü geçmektedir. Göktürk Devleti'ni yıkmak üzere Uygur Türkleri ile ittifak yapan Kırgız Türkleri VIII. asırda da Uygurları yurtlarından 
sürerek "Kırgız Devleti"ni kurmuşlardır. Daha sonra Kalmuk ve Moğollara karşı çetin mücadeleler veren Kırgızlar, 18. asırda Türkistan'da ortaya çıkan hanlıkların buyruğu altına girmişlerdir. Kırgızistan ülkesi, 1860-1881'de Ruslar tarafından işgal edilmiş ve 1991 yılına kadar Sovyetler Birliği bünyesinde bir asimile süreci geçirmiş, birliğin çözülmesiyle de bağımsızlıklarını elde etmişlerdir.

\section{Manas Destanı Üzerine Çalıșmalar}

Manas Destanı üzerine ilk ciddi çalışmalar 19. yüzyılda yapılmaya başlanmıştır. Manas Destanı'nı ilk olarak yazıya aktaran ve edebiyat dünyasına tanitan Kazak Türkolog Çokan Velihanov'dur. Velihanov, 1856 yılında Isık- Köl çevresine düzenlemiş olduğu seyahat sırasında Karkara Yaylası'na uğramış ve destanın bir bölümünü burada tespit etmiş̧ir. Çokan'ın tespit ettiği "Köketay Han'ın Aşı" diye adlandırılan bu bölüm, büyük ilmî değere haiz nüshalardan biri olarak kabul edilmektedir. Çokan'ın Manas Destanı ile ilgili üzerinde en çok durduğu konu, destanın muhteva plânı ve aydınlattığı devirlerdir. Çokan'ın Manas Destanı ile ilgili ilk incelemesi 1861 tarihinde "Rus Coğrafya Cemiyeti Yazıları" mecmuasının I. ve II. Kitaplarında yer almıştır. Çokan Velihanov bu incelemesinde Manas Destanı'nı şöyle tarif etmektedir:

"Sarp kayalarda yaşayan Kirgızlarda tek bir destan vardir. Bu destan Nogay devrine ait olan Manas Destani'dır. Bu destan Kırgızların mitolojisini, masallarını her türlü geleneklerini bir kahraman çevresinde toplamış Kırgız ansiklopedisidir. Kırgız Ilyadası gibi bir şeydir. Kirgızların hayat tarzları, gelenekleri, görenekleri, ahlâk ve dini telâkkileri, coğrafyası tıp bilgileri, başka uluslarla olan ilişkileri bu destanda ifadesini bulmuştur." (Velihanov Çokan Eserleri, 71-72)

Söz konusu eser üzerine çalışan bir başka ilim adamı da ünlü Türkolog W. Radloff'tur. Radloff, Manas Destanı'nı bir bütün olarak yazıya geçirmiş̧ir. W. Radloff 1862, 1864 ve 1869 yıllarındaKırgızistan'a yapmış olduğu seyahatler esnasında birçok manasçıdan destanın farklı varyantlarını dinleyerek not almış ve daha sonra bu bölümleri birleştirerek yazıya geçirmiştir. Derlediği bu bölümleri 1885 yılında St. Petersburg'da "Proben der Volkslitteratur der Türkischen Stämme/Kuzey Türk Boylarının Halk Edebiyatlarından Örnekler" adlı 11 ciltlik eserinin V. cildinde Kırgızca-Rusça-Almanca olarak yayınlamıştır. Radloff 
bununla da kalmayıp destanı Almancaya çevirerek tüm dünyaya tanıtmıştır. Radloff'un yayınlamış olduğu "Manas Destanı" 12.452 mısradan ibarettir. Bu mısralar içeriklerine göre şu şekilde gruplandırılmaktadır:

a) Manas'in Doğuşu:

1649 misra

b) Almambet'in İslâmiyet'i Kabulü, Gökçe'ye ve sonrasinda Manas'a ilticasi:

1862 misra

c) Manas'la Gökçe'nin Muharebesi, Manas-Kanıkey Evliliği ve Manas'ın Öldükten Sonra Dirilmesi: 2686 mısra

d) Bokmurun: 2595 misra

e) Köz Kaman: $2540 \mathrm{misra}$

f) Semetey'in Doğuşu ve Semetey:

$1078 \mathrm{misra}$

Radloff, söz konusu esere 26 sayfalık bir ön söz yazmış fakat bu önsözde Manas Destanı'ndan ziyade destanların içeriği, Türk destanları ve Türk şiiri üzerinde durmuş̧tur.

Manas Destanı'nın bugüne kadar on üç varyantı derlenmiş ve büyük bir bölümü yayımlanmıştır. Bir bölümü de henüz yazım hâlindedir. Eser üzerine çalışma yapan bir diğer bilim adamı da L. Von Almasy'dir. Almasy, Manas Destanı'nın el yazma niteliğinde olan bir nüshasını görmüş ve çalışmalarını bu nüsha üzerine bina etmiştir. Bir makalesinde; "Semetey" ve "Seytek" destanlarının otuz bin beyitten, "Manas"1n ise yirmi bin beyitten oluştuğunu belirtmiş ve gerçek bir halk destanı olan bu eserin İslâmî tesirlere maruz kaldığını dile getirmiştir. Destanın tüm varyantlarıyla ve plânlı bir biçimde yazıya aktarılması ancak 20. yüzyılda mümkün olabilmiştir. Eserin ilk bölümü ünlü Manasçı Sagımbay Orazbakov'un ağzından 1922-26 yılları arasında kaleme alınmıştır. Bu manasçının ölümü üzerine destanın 3. bölümü Sayakbay Karalayev'in ağzından tümüyle yazıya aktarılmıştır. Destanla ilgili önemli çalışmaları ve özellikle bu konuda Aytmatov'a ilham kaynağ1 olan bir başka araştırmacı ise Kazak yazarı Muhtar Avezov'dur. 1920 yılı itibariyle Kırgız coğrafyasında araştırmalarına başlayan Avezov, bu araştırmalarıyla Kırgız edebiyatı üzerine yapılan araştırma ve incelemelere öncülük eden önemli bilim adamlarından biri olmuştur. Avezov'un 1930 y1lında başladığ 1 çalışmalar otuz yıl sürmüş ve bu vesileyle destanın halk arasında yaşayan birçok varyantı ortaya çıkarılmıştır. Avezov, çalışmaları süresince Kırgız edebiyatının önde gelen yazar ve şairleriyle (Tügölbay Sıdıkbekov, Kasımaalı Bayalinof, Temirkul Ümitaliyev gibi) 
görüşmeler yapmış, onlardan bilgi almanın yanı sıra eserleri üzerine yorumlarda da bulunmuştur. Bu sırada Aytmatov ile de yakın temaslarda bulunmuş, yazarlık kabiliyetini keşfetmiş, desteklemiş ve özellikle Manas Destanı konusunda yol gösterici olmuştur. Bu nedenle Aytmatov; "Benim iki ilham kaynağım var: Biri Manas Destanı, diğeri ise Muhtar Avezof"(Alpısbayev, 1995: 27-31) demiştir. Ayrıca Avezov'un Manas Destanı üzerine yapmış olduğu uzun soluklu çalışmaları yakından takip eden Aytmatov, bir vesileyle kendisine yöneltilen “Nerelisiniz?"sorusuna, bir kadirşinaslık örneği göstererek "Manas'ın yaratıldığ "ve Avezov'un doğduğu yerdenim” (Manas Entsiklopediya I, II., 1995: 47)diye cevap vermiştir.

Farklı dönemlerde ve farklı manasçıların söyleyişleriyle tespiti yapılan, yazıya aktarılan destan varyantlarının sayısı yaklaşı olarak (60) altmıştır. Radloff varyantı 1862-1869, Sagımbay Orazbakov varyant1 1922-1926, Sayakbay Karalayev varyantı ise 1936-1956 y1lları arasında tamamlanmış ve her biri farklı bir hacimde olan varyantlar ortaya çımıştır. Radloff'un Colay ve Er Töştük epizodlarıyla birlikte tespit ettiği Manas Destanı 19.368 mısradan oluşmaktadır. Rejim baskıs1nın ortadan kalkmasıyla birlikte Manas Destanı üzerine çalışmalar daha bir hız ve yoğunluk kazanmış ve 1917-1924 yılları arasında yapılan çalışmalar neticesinde destanın 400.000 mısradan oluşan metni kayıt altına alınmıştır.

Manas Destanı'nın Türkiye Türkçesine kazandırılması ve Türkiye'de tanınması daha ileriki yıllara tekabül etmektedir. Bu konuda en büyük rolü Abdülkadir İnan üstlenmiştir. Destan üzerine yoğun çalışmalarda bulunan İnan, eseri nesir türünde Türkiye Türkçesine kazandırmakla kalmamış (1972-1992 yılları arasında olmak üzere üç kez basımı yapılmıştır), tanıtımına yönelik birçok makalenin de neşrinde bulunmuştur. Neşretmiş olduğu söz konusu dokuz makale "Makaleler ve İncelemeler" adlı eserde toplanmıştır.

Kırgız Türklerinin bağımsızlığını elde etmesinin akabinde iki ülke arasında meydana gelen yaklaşımlar doğrultusunda Kırgız kültürüne olan ilgi daha da artmış ve bu alandaki bilimsel çalışmalar hızını artırmıştır. Abdulkadir İnan'ın çalışmasına ilâveten Prof. Dr. Emine Gürsoy Naskali, Radloff tarafından derlenmiş olan destanı Türkiye Türkçesine aktarmıştır. Keneş Cusupov tarafından nesir türünde kaleme alınmış olan Manas metni ise Prof. Dr. Fikret Türkmen ve Alimcan İnayet tarafından Türkiye Türkçesine aktarılmıştır. Ayrıca Prof. Dr. Fikret 
Türkmen, "Manas Destanı Üzerine İncelemeler ve Çeviriler I" adlı bir eser de kaleme almıştır.

Türkiye'de Manas Destanı üzerine yapılan çalışmalar bununla da sınırlı kalmamıştır:

'W. Radloff'un 'Proben' adll eserinde yer alan ve 'Manas' başlığlyla anılan I. Bölüm üzerine Naciye Yıldız bir çalışma yapmiş ve yedi başlıktan oluşan bu çalışma doktora tezi olarak yayınlanmıştır. Bu çalışmalar günümüzde de devam etmekte olup makale ve bildiri düzeyinde birçok yayın bulunmaktadır.

Türkiye Devleti'nin öncülüğ̈̈nde UNESCO'ya yapılan başvuru üzerine 1992 yılında alınan karar neticesinde 1995 yılı 'Manas Yılı' olarak ilân edilmiştir. Bu doğrultuda 'Atatürk Kültür Merkezi Başkanlı̆̆ı'nın koordinatörlüğünde birçok etkinlik düzenlenmiş Manas Destanı ile ilgili birçok kitap ve makale yayınlanmıştır.

Bu doğrultuda en kapsamlı kutlama çalışmaları Bişkek'te gerçekleştirilmiş olup organizasyona Türkiye'den birçok akademisyen katılmiştır. Program dâhilinde 26-28 Ăgustos tarihleri arasında gerçekleştirilen 'Manas Destanı ve Dünyanın Epik Mirası' konulu bilgi şöleninde 226 bildiri yer almış, bu bildirilerin 22 tanesi Türkiyeli akademisyenler tarafindan sunulmuştur. Şölende Manas Destanı tüm yönleriyle ele alınmış, bu vesileyle tüm Türk dünyasının bir araya gelmesi sağlanmıştır." (http://tarih.sitesi.web.tr/manas-destaninin-olusumu-ve-icerigi.html 25.08.2015)

Türk boyları arasında son derece güçlü bir millî hafizaya ve sözlü edebiyat geleneğine sahip olan Kırgızlar, bu hafızanın en büyük eseri olarak Manas Destanı'nı kabul etmektedirler. Bu geleneğin yüzyıllar boyunca yaşatılması ve sonraki kuşaklara aktarılmasında en büyük rolü "manasçılar" üstlenmişlerdir. Manasçılar, destanı komuz eşliğinde dile getiren, jest ve mimiklerle destan kahramanlarının konuşma ve davranışlarını mekân ve olay örgüsü doğrultusunda tonlama/vurgulama yaparak canlandıran, devirlere göre bir ozan, âşık, meddah tarzında yorumlayan sanatçılardır. Manas Destanı'na tüm incelikleriyle vakıf olan manasçılara "Nagız Manasçı"; bütünüyle kavrayamamış olanlara ise "Şala Manasçı" adı verilmektedir. Nagız Manasçılar, icazet usulüyle devraldıkları bu mesleği geleneksel adabı ve erkânı üzere seslendirmekte, destanın üç büyük kolunu tüm epizotlarıyla canlandırmakta ve 
kesintisiz olarak canlandırdıkları destanı ancak altı ayda söyleyip tamamlayabilmektedirler. Bilinen en eski Nagız Manasçı XVIII. yüzyılın ikinci yarısında yaşamış olan Keldibek'tir. Bunun dışında kalan tanınmış manasçılar ise şunlardır: Kırgızlar'dan "Balık" lakaplı Bekmurat, Naymanbay, Al Çonbaş, Tınıbek, Çüyük, Sağımbay Orazbekov, Sayakbay Karalayev, Togolok Moldo, Şrısmendeyev, C. Kocekov, B. Sanazov, Cusup Mamay; Kazaklardan Cambil Cabayoğlu, Mayköt, Kulmambet, Süyimbay ve S. Mürsekoy'dur. Bugün de bu gelenek doğrultusunda Kırgızistan ve Kazakistan'da Manas Destanı'nı "Nagız Manasçı" ve "Şala Manasçı" olarak canlandıran Manasçılar bulunmaktadir.

Sayakbay Karalayev, Sagımbay Orazbekov ve Cusup Mamay en büyük manasçılar olarak anılmakla kalmayıp kendilerine özgü okuyuş biçimleriyle destanın farklı varyantlarının ortaya çıkmasına da vesile olmuşlardır. Dünya destanları arasında en uzun destan olma özelliğine sahip olan "Manas Destanı", üslubu ve içeriğiyle Kırgız kültürü, medeniyeti, tarihi, sanat ve edebiyat1, yaşam felsefesi ve folkloruna kaynaklık etmekte ve ayrıca evrensel boyuta ulaşması ve tanıtımına da vesile olmuştur. Bu yönüyle Manas Destan1, Türk kültürünün de en önemli kaynaklarından ve tanıtım araçlarından biri olarak anılmaktadır. Çünkü destanlar, diğer millî hafiza ürünleri gibi millet kavramını oluşturan kültürel kodları bünyesinde barındırmakta ve millî hafızayı oluşturmaktadırlar. Bu yönüyle Manas Destanı millî bilinci uyandıran ve canlı tutan manevî bir dinamik olarak kabul edilmiş, baskıcı Sovyet rejimi tarafından yıllarca engellenmiş ve yasaklanmıştır. Bununla da kalınmayıp destan üzerine çalışmalar yapan akademisyenler ağır cezalara çarptırılmıştır. Taşkent'te 1924 yılında yayınlanan, Komünist Parti yayın organı "Turkestanskaya Pravda" gazetesinin 23. sayısında Manas Destanı hakkında şu görüşler dile getirilmiştir:

"Manas Destanl, Pantürkizm ülküsünün inkişaf devrinde doğmuş̧ur ve destanin derlenen birinci ve ikinci bölümleri ırkçı milliyetçilik ruhuyla doludur. Manas Destanı ilim bakımından kiymetli bir eser olmakla beraber, Kirgizlartn ve diğer Türk kavimlerinin milli gelişmelerine zararl istikamet verebilir. Böylece biz buna karşı çok ihtiyatlı davranmalıyız. "(İnan, 1987: 111112) Ayrıca benzeri görüş, 1954 yılında yayınlanan "Büyük Sovyet Ansiklopedisi"nin 194-195. sayfalarinda yer alan "Manas" 
maddesinde dile getirilmiş; "Manas'ın bazı manasçılar tarafindan söylenen rivayetleri Pantürkizm ve Panislâmizm öğeleriyle doldurulmuştur."(İnan age: 218)

şeklinde çarpıtılmış ifadelere yer verilmiştir.

Rejimin destana karşı yanlı ve baskıcı tutumunu dile getiren bir başka görüş de Manas Destanı üzerine incelemelerde bulunan Bayciyev tarafindan dile getirilmiştir; "Sovyet rejiminin destanlar özellikle de Manas Destanı üzerine takındiğ bu katı tavır zaman zaman yumuşamasına rağmen 1980’lerin sonuna değin devam etmiştir. Bu dönem içerisinde Manas Destanı birçok defa ders kitaplarına girmiş, sonra tekrar zararlı görülerek çıkartılmıştır." (Bayciyev, 2004: 61-62)

Sovyet rejiminin Manas Destanı üzerine kurmuş olduğu baskı ve kısıtlamanın esas amacı daha önce de belirtildiği üzere kültürel asimilâsyon çerçevesinde gerçekleştirilen mankurtlaştırma, millî benliği ve kimliği yok etme çabasıdır. Çünkü Manas Destanı söz konusu hasletlerin canlı tutulması ve korunması, genç kuşaklara aktarılması hususunda en etkin etmenlerden biri olmuştur. Destanın yok edilmesi, bireylerin ve topyekûn milletlerin geçmişiyle olan bağlarını koparmanın en kestirme yolu olacaktır. Çünkü "Kişinin kendini çevreleyen şeyler dünyasinda yitip gitmemesi için, onun, tarihselliğini sağlayan bellek mekânlarına tutunması ve orada kurduğu kendilik bilinci ile hem uzamsal boyutta dünya ile hem de zamansal boyutta toplumsal geçmişiyle bağlantıya geçmesi kaçınılmaz bir gerekliliktir." (Korkmaz, age: 23)

Sovyet rejimi mantığıyla ele alıp aynı bakış açısıyla değerlendirildiğinde hiç şüphesiz Manas Destanı'nın bilinmesi, millî dilin bilinmesi, dil bilincinin pekiştirilmesi anlamlarına gelmektedir. Çünkü Kırgız Türklerinde dilin kutsallığı, başka bir kutsal değer taşıyan Manas ruhuyla birleştirilerek işlenmektedir. Diğer yandan Kırgız dili, özellikle Manas'ın kendi dili olması nedeniyle Kırgız halkı için büyük bir kutsallık arz etmektedir.

Ayrıca Kırgız halkı arasında yaygın olan bir inanca göre Kırgız soyu Manas'tan gelmekte ve bu hakikat büyük bir övünç kaynağı olarak kabul edilmektedir. Bu nedenle Kırgızların var olduğu en eski devirlerden beri Kırgız halkını bölmek, birlik ve beraberliğini bozmak amaciyla başvurulan en önemli yöntemlerden biri Manas ruhunu yok etmek olmuştur. Son devirlerde özellikle Sovyet döneminde bu süreç, medeni yöntemler eşliğinde ve profesyonel bir devlet politikası olarak 
işletilmiş ve Kırgız halkının Manas ile olan duygusal bağı koparılmaya çalışılmıştır. Ancak tüm bu çabaların sonuçsuz kalacağı, Manas'ın duası ve Kırgız halkının bedduasının buna imkân tanımayacağı inancını hiçbir etken yok edememiştir. Çünkü Manas Destanı ile varlığını sürdüren bu ruh millî birliğin sembolü olarak sonsuza dek yaşayacaktır. Kültürel açıdan belli isimlere bağlılık aynı zamanda sosyo-politik bir kimliğin onayını içerir. Manas ismi de belli bir isim etrafinda duyarlılıkları ortak kimliğe dönüştürmek için seçilmiştir. Çünkü; "ortak kimlik, ortak aidiyetin bilince çıkarılmasıdır." (Assman, 2001: 1349)

Manas Destanı ve Manas ruhunun yukarıda da dile getirildiği üzere millî-manevî bütünlüğü sağlayıcılığı ve zengin bir millî hafiza ürünü oluşu birçok dil bilimcisi ve araştırmacıların dikkatini üzerine çekmiştir. Ancak 20. yüzyılda söz konusu esere entelektüel bir bakış açısıyla yaklaşan, farklı bir bakış açısıyla ele alan ve eserlerinde işlemek suretiyle hem destanın evrensel boyuta taşınmasına hem de kendi eserlerinin bu destan vesilesiyle evrensel boyutta tanınmasına önayak olan Cengiz Aytmatov olmuştur. Millî hafiza ürünleri ile kültürel kodlara büyük önem veren Aytmatov, bağrından kopup geldiği geleneksel yapı nedeniyle Türk Dünyasının ortak mirası olan destanlar ile hassaten Manas Destanı'nın önem ve ayrıcalığını ruhunda sindirmiş ve düşüncelerini şu sözleriyle dile getirmiştir;

"Ilyada'dan sonra en büyük destan olan Manas Destanı ve diğer bütün Kırgız destanları beni çok etkiledi ve hâlâ da etkiliyor. Her eserimde bu destanlara dayaniyorum. Bin yll öncesinin halklar tarihi niteliğinde olan Manas Destanı bir milyon misradan oluşur. Kırgız halklarının tüm yaşantısinı tarihi ve Kara Kltaylara karşı özgürlük çatışmasını anlatır, tüm insan duygularını dile getirir, karş̧llıklı aşktan insan doğa ilişskisinden söz eder. Dört cilttlik bu destan yirmi yılda bir araya toplanmışttr. Tümü Kırgızca'dır. Çeşitli bölümleri yabancı dillere çevrildi, bir kısmını da ben Rusça'ya çevirdim. Bu destanların özü insan duygularıdır. Tekrarlyyorum her eserim bu Kirgiz destanlarina dayanir."(Erbay, 2002: 52-53)

\section{Aytmatov Anlatılarında Kazak Kültürü \\ Esintisi ve Kırgız Sözlü Geleneği/Manas Retoriği}

Aytmatov anlatılarında ilk etapta dikkatleri çeken folklorik unsurların temelini Kırgız-Kazak kültürü ile Kırgız sözlü edebiyat geleneğinin en zengin ifade vasıtası olan Manas Destanı oluşturmaktadır. 
"Manas Destanı, Kirgızların millîhafizalarının temel metni olduğu kadar Aytmatov'un da eserlerine temel teşkil eden kültür mirasindan biri, belki en önemlisidir. $O$, genç kahramanlarını Manas'a benzetir, onun kahramanlı̆̆ını değişik plâtformlarda da olsa genç nesillere aşılamaya çalışır." (Kolcu, 2008: 71) Malum olduğu üzere yazılı Kırgız edebiyatının, zengin sözlü edebiyatı kadar derin bir geçmişi yoktur ve yazılı süreç Sovyetler Birliği Dönemi'nde filizlenmeye başlamıştır. O güne dek bir sözlü edebiyat ürünü olarak varlığını sürdürmüş olan Manas Destanı ilk defa 19. yüzyılda "Radloff" tarafindan bilim dünyasına tanıtılmış ve kayıt altına alınmıştır. Manas Destanı'nın gün yüzüne çıkarılması bakımından hareketli ve parlak geçen bu dönem bir yönüyle de Cengiz Aytmatov'un yazarlık hayatının başlangıç yıllarına tekabül etmiştir.

Yazarlık üslubu ve orijinalitesini oluşturma çabası içerisinde olan Aytmatov, millî hafıza ürünü olan destanlar ve özellikle de Manas Destanı üzerine yoğunlaşmış, eserin üslup ve içeriklerini kendi üslubuyla bütünleştirerek kendine özgü bir tasvir, ritim ve tonlama ayrıcalığına dönüştürmüş böylece kendisini evrensele taşıyan orijinalitesini oluşturmuştur.

"Bir milletin kültür değerlerinin araştırılmasinda sözlü kaynakların yanı sira yazll metinler de bizlere önemli veriler sunmaktadır. Özellikle hikâye ve roman gibi kurmaca metinlerde sözlü kültürün etkisi ve geleneğin izleri çokça görülmektedir. Bir yazll anlatıda topluma ait kültürel değerlerin kullanımı oranı; yazarının içinden çıktı̆̆ toplumla ve o toplumun geleneksel değerleriyle ne ölçüde barışık ve kaynaşık olduğunun da bir göstergesidir.” (Şişman, Cilt V, 2007: 1965 )

Bir barışıklık ve kaynaşıklık örneği olan Aytmatov, Manas Destanı'nın ayrıcalıklı yanlarını ve bu destana yaslanmasının sebeplerini 1980 yılında Manas Destanı'na yazmış olduğu ön sözde şöyle dile getirmiştir;

"İnsanlı̆ğn durmadan devam eden hayat, hep istikbale yönelik olduğu hâlde yeni nesillerin hayat kaynağı ve mirası geçmişin tecrübeleridir. Başka türlü yeni medenî hayata erişmek mümkün değildir. Bu açıklama bilhassa dil mefhumunun tabiatına uygun düsser. 'Hünerin temeli dildir.' Diyen atalarımız bo- 
şuna söylememişler. (...) İşte millî dehadan doğan güzel söz hünerinin asll unsurlarl, karanllk devirlerden beri uzun yolculukları sırasında özündeki safiyetini kaybetmeden çağımıza kadar ulaşıp günümüz gerçekleri içerisindeki yerlerini alırlar.

Kırglz halkının bu ulu mirast-destan geleneği yukarıda da söylendiği gibi işte böyle bir ruh zenginliğine sahiptir. Kirgizların Orta Asya'nın en eski halklarından biri olduğu tarihi bir gerçektir. Kendisinin bu ezeli büyüme macerası Kırgız halkına destanî medeniyetin en güzel örneklerini verme imkânı bağışlamıştır. Başka halklar geçmiş medeniyetlerini, tarihlerini, yazll edebiyatla, heykelle, resimle, tiyatro ve mimarî ile muhafaza ederlerken, Kırgız halkı kendisinin, bütün düşünce ve duygularının ar-naтusunu, dünya görü̈sünü, ideallerini, tarihi hâdiseleri şifahî olarak destan şeklinde ifadeyi tercih etmiştir." (Aytmatov, 1982: 3-4)

Bu tercih, Kırgız kültürüne ait tüm millî -manevi değerlerin destanın bünyesinde toplanmasına ve zengin bir kültür hazinesine dönüşmesine neden olmuştur. Bu hazinenin farkına varan ve eserlerinde yararlanan Aytmatov, bu yönüyle aynı kulvarda yol aldığı çağdaşlarının önüne geçmeyi başarmış, mahalliden millîye ve millîden evrensele uzanan çizgiyi yakalamıştır. Yazar tarafından yakalanan bu çizgi bir Radloff mesabesinde tanıtıma vesile olmuş, destanın ve bir yönüyle de ortak Türk kültür ve medeniyetinin evrensel boyutta kendini duyurmasına katkı sağlamıştır. Aytmatov'un Manas Destanı'na dönük yüzü ve eserlerinde yer veriş biçimi çağdaşlarından tamamen farklı bir çizgidedir. Söz konusu destanın ortak Türk kültür ve medeniyetinin bir değeri olmas1 ve Aytmatov'un bu değeri global anlamda dünyaya duyurmas1 onun ikinci bir Manas/çağdaş Manas hüviyeti kazanmasına da neden olmuştur. Bu karşılıklı etkileşim Manas Destanı'nın Cengiz Aytmatov'un eserlerine ayrı bir sanatsal renk, ahenk, ritim, ş̧ık ve manevi güç katmasına vesile olmuştur. Böyle olmakla yazar, aynı zamanda ortak Türk dünyasının sesi olma rolünü de üstlenmiştir. Türkiye edebiyat otoriteleri de yaptıkları eser incelemeleri neticesinde Manas Destanı'nı Cengiz Aytmatov'un yüksek yazarlık yeteneği ve ilhamlarının en önemli kaynağı olarak kabul etmişlerdir. Ki yazar, U. Korkin ile yapmış olduğu bir söyleşide bu hakikati bizzat itiraf etmiş̧ir; "Benim iki ilham kaynağım var: Bunlardan birisi Manas Destanı, diğeri de, Muhtar Awezov'dur." (Alpisbayev, agm: 27-30) 
Yazarlık serüveni sürecinde Manas Destanı'nın ayrıcalığını fark eden ve ondan layıkıla feyz almasını bilen Aytmatov, destanı tanıma, tanıtma ve yararlanma konularında birlikte yola çıktığı ve aynı kulvarda yol aldığı çağdaşlarının önüne geçerek mahalliden millîye ve oradan da evrensele açılan kapıyı aralamıştır. Bu yönüyle yazar, amudi bir yükselişe geçmiş, yazarlık değerine kültürel kodlar noktasında yeni değerler katan bu eserin çağdaş manada ve evrensel boyutta anlaşılmasina/yorumlanmasina önayak olmuştur;

"Cengiz Aytmatov, Manas Destanı'nın Sovyet halkları arasında ve dünya çapında tanınması ve değerinin anlaşılması için de çaba sarf etmişstir. Meşhur şair Mirtemir, Manas Destanı'nı Özbek Türkçesine, Soloyhin ise Rusçaya çevirmek istediğinde, onlara yol gösteren Cengiz Aytmatov'dur. Cengiz Aytmatov'a sorulan 'Manas Destanı'nı dinlediğiniz zaman ă̆ladığınız oldu mu?' şeklindeki soruya, Aytmatov'un verdiği; 'Manas Destanı'nı dinlediği vakit ağlamayan Kırgız olmaz.' Şeklindeki cevabl, onun Manas Destanı'ndan sadece sanat veya ilim yönünden değil, duygusal yönden de etkilendiğini göstermektedir. Bu sebeple o, 'Manas Destanı'nı bilmeyen adam, öz milletini, dilini, yurdunu bilmez.' görüşündedir." (Yıldız, 8-10 Arlık1998: 214) der, Naciye Yildız.

Aytmatov'un Manas Destanı ile bu denli iç içeliği farklı bir anlayış ve bakış açısının da ortaya çıkmasına neden olmuştur ki bu durum Kırgız halkının Aytmatov'a olan bakış açısını ortaya koyması bakımından da son derece önemlidir; "Kirgızlar; "Manas denince Kirgız, Kırgiz denince de Cengiz akla gelir" derler. Cengiz Aytmatov'un toplumdaki saygınlı̆̆ını belirtmek için söylenilen bu ifade, zaman içinde atasözü karakteri kazanmış ve yeni yetişen kuşaklar arasında sanki Cengiz Aytmatov'dan önce söylenmiş bir söz gibi algllanmaya başlanmıştır. Gerçekte Kırgız halkı dünya çapında ün kazanmış sanatçısını bu sözlerle tanımlamıştır." (Sagınbekov, 2007: 1747-1752) Manas Destan1Aytmatov etkileşiminin günümüze bakan yönünü dile getiren bir başka ilim adamı da V. Korkin'dir; "Cengiz Aytmatov, romanlarinda Manas Destani'ndan ve Kırgız kültüründen faydalanır. Aytmatov, "Benim köklerim, masallar, halk hikâyeleri ve okyanus kadar zengin olan Kırgız destanı Manas'ın yapısında var olan halk şiirinde." (Korkin,Mart 1993: 204) şeklindeki ifadeleriyle yazarın kendi dilinden bu özdeşleşmişliği pekiş̧irir. 
Yukarıda dile getirilen ifadeler araştırmacı ve yazarların dıştan gözlemleyerek ve Aytmatov eserlerini tahlil ederek ortaya koymuş oldukları izlenimler olmakla beraber yazarın kişisel görüşleri de bu ifadeleri destekler mahiyettedir. Yazar bir söyleşisinde; "Biz Manas Destanı'ndan, halk edebiyatımızdan ve Rus edebiyatından faydalandık." (Deliömeroğlu, sayı 19, 2008: 65-66) ifadesiyle dayandığı kaynakları nazara vermekte bir başka sözüyle de bunu teyit etmektedir; “...Eski sözlü edebiyat geleneğimiz, özellikle eski destanlar, halk öyküleri, içlerinde en önemlisi Manas Destanı. İkinci kaynak ise Sosyalist Sanayi Dönemi Edebiyatıdır. ...Böylece hem geçmişimizi, geleneğimizi sürdüren, hem de yeni yaşamımızı içeren iki kaynaklı bir edebiyat oluşuyor. ..." (Oral, 1976: 414)

Yukarıdaki görüş ve ifadelere paralel görüş ortaya koyan bir başka araştırmacı ise Naciye Yıldız'dır. Yıldız, Aytmatov anlatıları üzerine yapmış olduğu araştırma ve analizlerinden yola çıkarak elde ettiği tespitlerini şöyle dile getirir;

"Manas Destanl, Cengiz Aytmatov'un beslendiği önemli kaynaklardan biridir. Yazarın Cemile isimli uzun hikâyesinden en son romanına kadar yazdiğı eserlerin hemen hepsinde yer alan destansı üslup, kahramanların özellikleri, iç dünyalarının tahlili, hümanizm, felsefi düşüncelerin aksi, gelenek ve ahlâkla ilgili problemlerin ele alınışı, bu ulu kaynağın Cengiz Aytmatov'da açıkça takip edebildiğimiz izleridir. Manas Destanı ile şaheser seviyesine ulaşan Kırgız, şifahî edebiyatının çağdaş edebi türlere nasll işleneceğini gösteren bu eserler, Kırgız Kültürünün yaşatılması ülküsünün de canlı birer abidesi durumundadır." (Manas Entsiklopediya 1. Tom, 1995: 46)

Yukarıdaki ifadelerden de anlaşıldığı üzere Cengiz Aytmatov'un eserlerinde görülen folklorik malzemenin temelinde Kırgız kültürü ve Kırgız sözlü geleneğinin en güzel ifade vasıtası olarak kabul edilen Manas Destanı'nın olduğu açıkça görülmektedir. Yazarın tüm anlatılarında satır aralarına büyük bir ustalıkla sindirdiği "folklorik malzemenin temelinde asırlar boyu şekillenen Kırgız kültürü, Kırgız kültürü ve Kırgız sözlü geleneğinin en büyük ürünü olan Manas Destanı gelir." (Uzun, Volume 2/2 Spring 2007: 733) Aytmatov'u diğer çağdaşlarından ayıran en büyük özellik, destanın tasvir, ritim ve tonlamasındaki ince ve seçkin üslubu yakalayarak eserlerine taşıyabilmiş olmasıdır. Özellikle Ma- 
nas ruhunu oluşturan "hürriyet" kavramı Aytmatov için en önemli nirengi noktalarından birini oluşturmuş ve devrin rejim baskısı karşısında bir mankurta dönüşmeden kültürel kodları korumayı, asrın dejenerasyonuna karşı dik durmayı salık veren eserler kaleme almıştır. Yazarın bu yönü üzerine eğilen A. İhsan Kolcu tespitlerini şöyle dile getirir;

"... Yazarın birçok eserinde ön plâna çıkan temel gücün yani 'hürriyet' probleminin temel dayanak noktasının da manas destanı olduğunu söyleyebiliriz... Bu düşünce destanda ilk şekliyle ve bir bakıma 'ham' biçimiyle vardır. Onu, ondaki bu temel fikri işleyecek, edebi ve estetik kalıplar içinde günün şartlarına uyarlayacak, ondan evrensel mesajlar çıkaracak Aytmatov gibi usta kalemlere ihtiyaç vardır. Bu, tıpkı ressamın, heykeltıraşın, mimarın kullanacă̆ $\breve{l}_{\text {ana }}$ malzemenin tabiatta ham şekliyle var oluşu gibi, edebiyatla uğraşan sanatkârın kullanacă̆ ham malzeme de bu millî metinde mevcuttur. Aytmatov bu malzemeden güzel eserler çıkarmasını bilmiş bir sanatkârdır." (Kolcu, age: 177)

Kolcu'nun tespitini teyit eder mahiyette konuyla ilgili görüşlerini dile getiren Aytmatov, anlatılarında genel itibariyle böyle bir üslup sergilemesinin nedenlerini şöyle izah eder:

"Bizde mitolojik ürünler çok zengin. Benim bilakis çocukluk zamanında başımdan geçen pek çok hadise bana ışık tutmuştur. Beş altı yaşında babamın annesi Ayıkman çok sohbete düşkün bir insand, eski kültüre vaklf bir insand, irticalen şiirler söylerdi. Ben onun yanında büyürken devaml onun ninnilerini, masallarını, efsanelerini dinlerdim. Köylerde, yaylalarda onunla birlikte dolaşırken bana hep bir şeyler anlatırdı. Ben buna öyle alışmıştım ki onu her gördüğümde bir şeyler anlatması için ısrar ederdim. Saatlerce anlatırd v ve artık konusu kalmazdl. Bu sefer, 'Yavrum müsaade et biraz uyuyayım, gördüğüm düşü anlatayım.' Derdi. Iște ninemin anlattıkları bende çok büyük bir zenginlik yarattı." (Aytmatov, Şubat 1992: 12, 13 ve 24)

Aytmatov, Kırgız halkının varoluş tarihi boyunca sergilemiş olduğu görüş, düşünce ve yaşam felsefesini havi Manas Destanı aracıl1ğıyla bir yandan Kırgız kültürünü evrensel boyuta taşırken diğer yandan kişisel görüş ve düşüncelerini de evrensel boyuta taşıma olanağ1 bulmuştur. Çünkü Aytmatov'un kahramanları "Manas'ın” ruhundan ateş almış güçlü karakterlerdir. Momun, Tanabay, Yedigey, Kazangap 
gibi yaşlı kahramanlarda Bakay'ın birtakım karakter özelliklerinin yansımasını, onun üstün akıl ve zekâsını, halkını, memleketini, gençlerin geleceğini düşünme hasletini; kadın Tolgonay Ana, Cemile, Asel ve Altınay'da ise Çıyırdı'nın, Kanıkey'in, Kız Saykal'ın, Ayçürök'ün ruh hassasiyetini, keskin zekâsını, sabrını ve dayanma gücünü, içtenlik ve samimiyetini her an ve olayda görmek mümkündür.

"Cengiz Aytmatov'un eserlerinde kadın tiplerine bakttğlmızda Cemile'nin sevdiğinin ardından giden Ayçürök, Tolgonay'ın Manas'in ölümünden sonra ekin ekip biçmek zorunda kalan anası Çıylrdl, Gün Olur Asra Bedel'de Zarife'nin, Yüz Yüze'de Seyde'nin Manas'ın eşi Kanıkey gibi güçlü ve mücadeleci kadınlar oluşu da dikkat çekmektedir. Bu karakterler ile Aytmatov, Destan dönemi kadının sahip olduğu statüyü hatırlatarak çă̆ımız kadınlarının da tekrar aynı seviyeye gelişini arzulamaktadir." (Yildız, agm: 223)

Manas Destanı'nın Aytmatov'un eserleri vesilesiyle çağdaş anlam ve evrensel boyuta taşındığını görmek ve kavramak adına yazarın eserlerinde ön plâna çıkan birtakım motif ve ritüeller üzerinde durmakta büyük fayda vardır. Konuyla ilgili derin analizleri bulunan Naciye Yıldız, "Beyaz Gemi" anlatısından yola çıkarak aşama aşama "Elveda Gülsarı", "Cemile”, "Erken Gelen Turnalar", "Gün Olur Asra Bedel" anlatılarını mercek altına almış ve son olarak "Yıldırım Sesli Manasçı" ile noktayı koymuştur.

Aytmatov anlatıları üzerine yapılan incelemeler neticesinde "Manas Destanı" ve "manasçı" kavramının en fazla yer ettiği ve çağdaş manada tanınması hususunda en büyük misyonu eda ettiğine dair kanaatlerin buluştuğu eser "Yıldırım Sesli Manasçı"dır. Çünkü millî hafızanın nirengi taşı Manas Destanı'nın Kırgız halkı ortak Türk dünyası ve kültürünün bekası açısından ne büyük bir öneme sahip olduğunu yerelden evrensele dillendiren "Yıldırım Sesli Manasçı" anlatısı olmuştur.

Anlatıda Kertolgo'nun oğlu Eleman için:

"Ey kadere hükmeden Kök Tengri! En küçük oğlum Eleman'ı getirdim, ondan başka çocuğum olmayacak artık. Çocuk doğurmayacă̆ım. Mademki babasının mesleğiyle ilgileniyor, o sanatın yeteneğini, Senirbay'ın ustalı̆̆ını ona da ver.

Ĕger yurtçu olmazsa, ağabeyi Koyçuman gibi bir Manasçı, Manas ozanı olmak istiyor. Bari ondan bunu esirgeme. 
Ona, ataların güzel konuşma yeteneğini ver. Bu yetenek onda köklü bir ă̆aç gibi gelişsin ve sonra o, bu yeteneğ $i$, bu geleneğ $i$ çocuklarına, torunlarına aktarsin. Bu yetenek kuşaktan kuşağa ulaşsın. Kirgızlar Kırgız olalı beri var olan Manas'ı iyi öğrenmesi, unutulmaması için ona güç ve cesaret ver!"

(Aytmatov, 1993: 15)

Şeklindeki duası, aslında Aytmatov'un Manasçının ve özellikle Manas Destanı'nın Kırgızlar için nasıl bir kutsallık arz ettiğini, Manas okumanın yanı sıra dinlemenin faziletini, baskıcı rejimin destana, okuyana ve dinleyenlere karşı tavrını, ortaya koyması açısından oldukça önemlidir.

“Cengiz Aytmatov, 1952 yllinda Bişkek'teki SSCB İlimler Akademisi Kırgız Bölümü'nde 'Manas Destanı; zengin feodal devrinin Hanlık yönetimini isteyen, halka yabancl, gerici bir eserdir.' iddiasinın tartışıldiğını ve Muhtar Avezov'un akıllı, dirayetli savunmast ile bu iddianın çürütüldüğ̈̈nü söyler' (Aytmatov-SSahanov, 1998: 67). Ayn toplantıda A. Tokombayev, 'Manas'in yararl kime?' (Asanaliyev, 1995: 93) diye Manas'in gerici, feodal öğeler taşıyan bir destan olduğu için anlatımının yasaklanmasını savunurken, P. I. Baltin ise, "Manas Destanı'nı bütünüyle yok etmek gerekir." (Asanaliyev, age: 96) der. Stalin'in kendini putlaştırdığ bir zamanda, bu zalimce iddiaları cesurca ve dirayetle göğ̈̈sleyen, cevaplayan Muhtar Avezov ve B. M. Yunusaliyev, Manas'ın bütünüyle ortadan kaldırlmasinı önlemelerine rağmen yine de 1952-1954 yillar arasinda Manas'ı anlatmak ve üzerine çalışmalar yapmanın resmen yasaklanmasının (Akpınar, 1986: 13) önüne geçemezler." (Korkmaz, age: 75-76) Yine aynı ortamda konuşmacılardan biri olan Boronkov ise; "Manas, Partinin şimdiki politikasina ters düşen bir eserdir. Aramızda yaşamakta olan Pantürkizm 'in gözüdür" iddiasında bulunur. (Aytmatov-Şahanov, 1998: 68)

Tarihî bilgilerin ışığında görülmektedir ki, Sovyet rejimi, Manas Destanı ile bin yılın ötesinden çağlayıp gelen uyarıcı ve diriltici sesi millî ve manevi benlik ve bilincin uyarıcısı, dirilten bir muştucusu olarak algılamış ve kendi sistemleri adına bir tehlike olarak kabul etmişlerdir. Ulaştığı çölleri ve kurak iklimleri dirilten su gibi Manas'la çağıldayan ses, söz ve ritmin de sihirli tesir ve gücünden korkan düşman 
gerçek yaşamda nice Eleman'ları katlettiği gibi paralel çizgide bu gerçeği dile getiren "Yıldırım Sesli Manasçı" anlatısında da Eleman'ı insanlık dışı işkencelerle yok etmişlerdir. Aslında bu tavır, bellek alanlarını belirleyen kültürel kodlara bir saldırıdır. Amaç ise bu kültürel kodları bünyesinde barındıran en önemli bellek alanlarından birisi hatta Kırgız halkı için en önemlisi olan Manasçının imhası yoluyla asıl hedefe ulaşmak ve Manas Destanı ile Manas ruhunun varlığına bir son vermektir. Bu vesileyle geçmişle bağlantıyı kuran tüm köprüler yıkılmış, bireyler topyekun öz benliğinden arındırılmış, doğal bir mankurtlaştırma süreci başlatılmış olacaktır. Bu yöntemle tüm tutunma, dayanma objeleri tahrip edilmiş olan tutarsız ruhlar mutlak itaat çerçevesinde "atadan kalgan tuyak"tan uzaklaşmış olacak, yaşanan tahripler neticesinde boşalan alanlar rejim tarafindan belirlenen kodlara açık hâle getirilecektir. Belirlenen süreç ve metotlar çerçevesinde aşama aşama boşalan alanlar doldurma/yerine koyma metoduyla rejime dönük kodlarla doldurularak kişilik ve kimliğinden uzaklaştırılmış, öz güvenden arındırılmış mankurt soylu kuşaklar yaratılmış olacaktır.

Oysa farklı devirlerde farklı kuşaklara ait Manasçılara yönelik uygulanan zulüm politikalarını yakından bilen, gözlemleyen Aytmatov, gelenekten gelen algı ve anlayışı doğrultusunda destana ve destancılara kendince bir kutsiyet atfetmiştir. Her bir Manasçıyı tanrı tarafından özellikle seçilmiş ve millî kültürü yaşatmak adına özel olarak görevlendirilmiş birer muştucu olarak görmüş ve göstermek istemiştir.

"Çocuk, Tanrı'nin onu Çungar boyunduruğu altında geçen o korkunç mücadele ylllarında, umut veren, millî kültürü yaşatan bir muştucu olarak seçtiğini de bilmiyordu. Düşmanin onun başını getirene bir safkan atı ödül vereceğini, bir hain çıkıp da onu düşmana teslim ettiği zaman gözlerinin oyulacağını, kavurucu Kazak bozkirina salvverileceğini ve dayanilmaz işkenceler altında yitip gideceğini de bilemezdi." (Aytmatov, age: 18)

Ayrıca yazar tarafından rejimin korku ve baskı terörü üzerine dikkatler çekilirken bir yandan da bu teröre karşı Manas okuma ve dinlemenin Kırgız ruhuna vermiş olduğu teselli duygusu bilinçaltına kazınmaktadır. Yazarın yukarıdaki sözlerinde ifadesini bulan teselli dinginliği, destanın milletin ölmezliğini belgeleyen içtenliği, manevi derinliği ve kahramanlık sahneleriyle ön plana çıkan görkemi bu anlatıda olduğu gibi diğer anlatılarında da kendini göstermektedir. Ayrıca Sovyet rejiminin millî olana karşı tepkisi ve millîliği muştulayan 
kültür önderlerine karşı uyguladığı zulmü, söz konusu eserde destansı motif ve ritüeller perde yapılmak suretiyle bir çağdaş Manasçının sesinde yankısını bulmaktadır;

"O anda, annesinin o gün yaptı̆̆l duayı ömrü boyunca unutamayacă̆ını bilemezdi. Onu her zaman gözyaşı dökerek hatırlayacă̆ını, kendisine manas anlatma yeteneği verdiği için Tengri'ye ve bunu Tengri'den istemiş olan annesine her zaman şükredeceğini de bilemezdi. Manas anlatma yeteneği gelişecek, gelişecek ve o, "Yıldırım Sesli Manasçı" olarak ün yapacaktı. Eleman'ın o gün bilemediği şeylerden biri de, gençlik yıllarının Oyrat terörü altında kahramanca bir mücadele ile geçeceği, Kırgızların ondan Manas' $ı$ dinlemek için gizlice dağların uzak kuytularına, boğazlarına gitmek zorunda kalacaklarlydı. Manas'l anlatmaya başladı̆̆ zaman, her defasında, manasçı oğlunun saklandiğl yeri söylemediği için işgalciler tarafindan öldürülmüş olan annesini, gölbaşında dua ederken canlandıracaktı gözünde. Ve yine her defasında Manas'l anlatmak onun için hem bir teselli olacak, hem de o, milletinin ölmezlik ruhunu simgeleyen, ululayan bu atalar mirası destanının görkemini, derinliğini, güzelliğini daha içten duyacak ve duyuracaktı. Kader ona, kor-kudan nefesi kesilenlere Manas'ı anlatmak, Manas'ı hatırlatmak görevi verecekti." (Aytmatov, age: 15-16)

"Yıldırım Sesli Manasçı" anlatısında yazar, destanın atmosferinde kaleme aldığ ve Manas ruhuyla sonlandırdığı eserin konusunu, üslup ve yapısını doğrudan doğruya özgürlük ile bağımsızlık ideolojisi üzerine kurmuş, ince bir ustalık ve Aytmatov'a özgü bir orijinalite çerçevesinde biçimlendirmiştir. Yazar tarafından destanın ölümsüzlüğü, Kırgız halkının tükenmek bilmeyen mücadeleci ruhuna dayandırılmakta, Kırgız halkına bu ruhu kazandıran motivasyon kaynağının ise kutsal Manas ruhu olduğu önemle vurgulanmaktadır. Eserin başkahramanı Eleman'ın kaderiyle bir bağ kurularak ifade edilen bu hakikati yazar, Kertolgo'nun duasında açık bir yüreklilikle dile getirmektedir. Kertolgo'nun ilk olarak atının başını çevirdiği (yöneldiği) yer Issık-Göl'dür. Kertelgo bu kutsal göle yönelerek seslenir ve insan-lığ yok eden acımasız savaşların zulmünden Kırgız halkını koruması için temennide bulunur. Oyrot Savaşı'na giden askerlerin sağ-salim ve zafer kazanmış olarak geri dönmesini ve özellikle oğlu Eleman’ı Manas’ın 
kutsal ruhunun korumasını, iyi bir Manasçı olarak yetişmesini diler, dua eder.

Görüldüğü üzere, milliyetçi Kertolgo’nun ilk dileği/duası halkının emniyeti ve iyiliği iken ikinci temennisi kutsal Manas ve Manasç1l1k ruhunun ebediyet kazanması, oğlu Kertelgo'nun da bu ebediyet yolculuğunda bir şanlı bir Manasçı olarak rol almasıdır. Millî Romantizm ekseninde Aytmatov anlatılarına mercek tutan Ali İhsan Kolcu da Yıldırım Sesli Manasçı anlatısını merkeze alarak AytmatovManas Destanı etkileşimini şu şekilde yorumlamıştır: "Yıldırım Sesli Manasçı hikâyesinde temel unsur Manas Destanı'dır. Bu destan etrafinda, oluşacak millî şuur Kırgızlart yeniden hürriyetlerine kavuşturacaktır. Aytmatov bu eserinde (Sultanmurat hikâyesinden farklı olarak) ilk defa bu kadar geniş ve belirgin bir surette bu destana yer verir. Hatta daha da ileri giderek destanın Kırgızlar için taşıdı ğ ehemmiyeti bir hitabet edasında anlatır." (Kolcu, 1997: 140)

Manas Destanı ve Manas ruhunun bireyler üzerinde kimlik, kişilik ve öz güven oluşturan ve bu bilinci pekiştiren, coşturan ve kanatlandıran büyülü gücü Aytmatov anlatılarına aynıyla yansımıştır. Örneğin, "Cemile" romanında ikinci dünya savaşına gitmek üzere tren istasyonunda toplanmış olan Kırgız askerleri: "Bozkır yardımcınız olsun! Kahraman Manas'ın ruhu yardımcınız olsun!” (Aytmatov, 1993: 248) diyerek uğurlanırken uğurlanan askerler de aynı dileklere katılarak Manas'ın kollayıp gözeten ruhuna sığınırlar. Yine merkezine aynı savaşın oturmuş olduğu "Sultanmurat" anlatısında: "Her verilen emri yerine getirmeye hazırdılar. Karşılarındaki bu savaşçı sanki manas idi: Kır saçl, zırhlı, heybetli manas! Ve kendileri de onun sadık, yiğit batırları. Kılıçları bellerinde, kalkanları ellerindeydi." (Aytmatov, 1993: 106) Ífadeleriyle kahraman Manas portresi çizilerek Kırgız gençlerinin bu resim üzere kendine çeki düzen vermeleri ve aynı ruh üzere sadık, yiğit birer bahadır olmaları yönünde telkinlerde bulunulmaktadır. Aynı eserin bir başka yerinde ise; "Beş çocuk atlarını koşturup açmaya çıkmışlardl. Her biri kendi savaş atına binmişti. Sultanmurat Çabdar'a, Anatay Oktoru'ya, Erkinbek Akbaypak'a, Ergeş Altuntuyak'a, Kubatkul Cibekcala'ya. Her zaman yaptıklart gibi hayvanları tırısa kaldırıp avlunun etrafinda bir tur attılar. Sonra yola girip köyden çıktılar." (Aytmatov, age: 111)ifadesi içerisinde yer alan "Her biri kendi savaş atına binmişti. ” cümlesi her firsatta Kırgız gençlerine savaşçı bir Manas ruhu aşılamanın örneklerini sergilemektedir. 
Manas Destanı'na telmih amacı güden ve daima hatırlarda canlı kalmasını hedefleyen, her firsatta Manas ruhunu bilinçaltına işlemeyi amaç edinen Aytmatov, yalnızca savaş figür ve ritüellerinde değil, duygusal anlamda aşkı, sevdayı işlerken bile bir ölçü, bir boyut belirleme amacıyla mihenk taşı kabul ettiği Manas Destanı'na telmih ve atıflarda bulunur. Örneğin; Hacımurat, ağabeyi Sultanmurat'ın güzeller güzeli Mırzagül'e âşık olduğunu duyduğunda sevincinden kendini kaybeder ve

“- Tamam! Tamam! Bağırmam artık. Onu seviyorsun ha! Tipk Ayçörek ve Semetey gibi değil mi?

-Öyleyse çık şu dağlara da avaz avaz bağır, bütün dünyaya ilan et!

-Çılkar bağırırım, ne olacak! Mirzagül'ü seviyorsun iște! Seviyorsun' Seviyorsun!.." (Aytmatov, 2014: 148)şeklinde bir ifadeyle aşklarına duyduğu saygıyı ve bu aşkın büyüklüğünü kendince tarif etmeye çalışır. Bu durum aynı zamanda Kırgız halkının yalnız savaş söz konusu olduğunda değil, beşikten mezara uzanan kulvarda, hayatın her an ve alanında Kahraman Manas ile özdeşleştiklerini veya öyle olmaları gerektiğini açıkça göstermektedir.

Aytmatov anlatıları ve Manas Destanı üzerine yapmış olduğu ça1ışmalar esnasında Manas ruhuyla özdeşleşen Naciye Yıldız, "Cengiz Aytmatov ve Manas Destanı" adlı çalışmasının bir aşamasında Aytmatov'un duygusal dünyasına dalar ve "Ben tipkl Ylldırım Sesli Manasçı'da Eleman için olduğu gibi, Cengiz Aytmatov için de bir ananin dua ettiğine, yazarın, bu duanın gücüyle sözlerini, imkânsızı gerçekleştirerek bütün dünyaya duyurduğuna inaniyorum." (Yıldız, agm: 225) sözleriyle Manas ruhunun koruyucu ve kucaklayıcı gücüne işaret eder.

Hiç şüphesiz ki Manas Destanı, Aytmatov'a farklı bir orijinalite kazandırarak gerek üslup ve gerekse içerik bakımından aynı kulvarda yol aldığ 1 çağdaşlarına nazaran bir üstünlük ve ayrıcalık kazanmasını sağlamıştır. Bu ayrıntı üzerine yoğunlaşan araştırmacılardan biri olan Kolcu, Manas Destanı'nın Aytmatov için önemine vurgu yaparken;

"Millî olandan evrensele ulaşmada Cengiz Aytmatov'un

Türk Dünyast yazarlart içerisinde çok önemli bir yeri vardır. $O$, eserlerinde 'geleneksel kültür unsurları'nı kullanarak millî hissiyatl, bütün insanlı̆g kucaklayan ortak zevk ve estetik duyarllk hâline dönüştürür. Aytmatov'un eserlerinde halk kültürünün pek 
çok çeşidini bulmak mümkündür. Geçmişi bugünle değil, bugünü geçmişle izah etmeye çallşan yazar; eserlerinde folklorik unsurları bolca kullanarak geçmişte yaşanilan ve milli hafizada canl-lı̆̆ını koruyan hâdiseleri bir model vak'a durumuna getirir. Bir efsane, bir destan, bir masal, büyük bir hadise bugünün olayın açıklayıcı mahiyettedir. Onun eserlerinde destan parçaları, efsaneler, masallar, halk hikâyeleri zengin bir malzeme durumundadır. Aytmatov'un eserlerinde ön plâna çıkan folklorik malzemenin temelinde Kırglz Geleneği ve Manas Destanı vardır. Manas Destanı yazar için, Kırgız ruhunun şekillenip nazma büründüğü bir halk ansiklopedisidir. (Kolcu, age: 56) ifadelerine yer verir.

\section{Sonuç}

Aytmatov'un eserlerinde Manas Destanı'nın etki ve izlerini yalnızca bu destandan alınan mitolojik unsurlar, birebir ifadeler ve metinlerde aramak ve bununla sınırlandırmak yanlış bir kanaat olacaktır. Çünkü yazar, eserlerine Manas ruhunu sindirerek bu ruhu gelecek kuşaklara aktarmayı hedeflemiş̧ir. Manas Destanı, Kırgız millî ruhu ve hafizasının oluşmasında nasıl büyük bir rol oynamışsa Aytmatov anlatıları da oluşan bu ruh ve hafizayı canlı tutan, besleyen kültürel bir zenginlik ve millî hafıza hazinesinin koruyucusu ve aktarıcısı olarak üzerine düşen görevi yerine getirmiş, getirmeye de devam etmektedir. Bu yönüyle denilebilir ki Aytmatov anlatıları, Manas Destanı'nın modern ve güncel bir varyantını oluşturmaktadır.

\section{KAYNAKÇA}

AÇA, Mehmet (2002); Kazak Türklerinin Destanları ve Destancılık Geleneği, Konya: Kömen Yayınları.

AKPINAR, Yavuz (1986); "Manas Destanı", Türk Dili ve Edebiyatı Ansiklopedisi, C:6, İstanbul: Dergâh Yayınları.

ALPISBAYEV, Kupıya (1995); "Kazak Âlimlerinin İncelemelerinde Manas Destanı", Manas Destanı ve Etkileri Uluslararası Bilgi Şöleni, Ankara: AKM Yayınları.

ASANALIYYEV, Keneşbek (1995); Çıngız Aytmatov, Bişkek.

ASSMANN, Jan (2001); Kültürel Bellek, Çev: Ayşe Tekin, İstanbul: Ayrıntı Yayınları.

ATSIZ, Hüseyin Nihal (1997); Türk Edebiyatı Tarihi, İstanbul: İrfan Yayınevi.

AYTMATOV, Cengiz - Muhtar ŞAHANOV (1998); Kuz Başındaki Avcının Çı̆̆lığı, Aktaran: Banu Muyaeva, Ankara: Tolkun Yayınları. (1982);"Kadim Kırgiz Ruhunun Zirvesi" Aktaran: İklil Kurban-Ali Akbaş, Erzurum: Kardaş Edebiyatlar Dergisi, Sayı 3. 
(1992); "Her Yazar Kendi Halkı İçin Yazmayı Nazarda Tutar", Mülâkat: Sabiha Özen, Dergâh Dergisi (Şubat), sayı 24. (1993); Cemile -Elveda Gülsarı, Yüz Yüze, Oğulla

Görüşme, Askerin Oğlu Hikâyeleriyle Birlikte-, Çev: Mehmet Özgül, İstanbul: Cem Yayınevi.

İstanbul: Ötüken Neşriyat A.Ş. (1993); Yıldırım Sesli Manasçı, Çev: Refik Özdek,

Ötüken Neşriyat AŞ., İstanbul. (2014); Cemile, Sultanmurat, Çev: Refik Özdek, BAYCIYEV, Mar (2004); Manas Destanı Kalbimin Ağrısıdır, Çev: Doğan Gürpınar, Bişkek: Manas Üniversitesi Sosyal Bilimler Dergisi, C. VI.

ÇETIN,Mustafa (1994);Cengiz Aytmatov'un Eserleri ve Eserlerinden Sinemaya Uyarlanan Filmler Üzerine Bir İnceleme, İstanbul: İstanbul Üniversitesi Sosyal Bilimler Enstitüsü (Yayımlanmamış Doktora Tezi).

DELİÖMEROĞLU, Yakup (2008);Cengiz Aytmatov'la Söyleşi, Ankara:

Kardeş Kalemler-Cengiz Aytmatov Özel Sayısı-Sayı 19.

ELİADE, Mircea (1993); Mitlerin Özellikleri, Çev: Sema Rıfat, İstanbul:

Kuram Yayinları.

ERBAY N., Kübra (2002); Cengiz Aytmatov'un Eserlerinde Tabiat, Ankara:

T.C. Kültür Bakanlığı Yayınları.

GEYIKOĞLU, Hasan (2001);Tarih Açısından Manas Destanı ve Sovyetler

Birliğindeki Türklerin Millî Duygularına Etkisi, Atatürk Üniversitesi, Türkiyat Araştırmaları Enstitüsü Dergisi, Sayı 16, Erzurum.

http://tarih.sitesi.web.tr/manas-destaninin-olusumu-ve-icerigi.html 25.08.2015

İNAN, Abdulkadir (1987); Manas Destanı, Ankara: Kültür ve Turizm Bakanlığı Yayınları.

KOLCU, Ali İhsan (1997); Millî Romantizm Açısından Cengiz Aytmatov, İstanbul: Ötüken Yayınları.

Salkımsöğüt Yayınları.

(2008); Bozkırdaki Bilge: Cengiz Aytmatov, Erzurum:

KORKIN, Vladimir (1993); Cengiz Aytmatov ile Söyleşi: Tercih: Robot veya İnsan Olmak, Çev: Orhan Söylemez, Ankara: Türk Dili Dergisi (Mart) Nr: 495.

KORKMAZ, Ramazan (2004); Cengiz Aytmatov Anlatılarında Ötekileşme Sorunu ve Dönüş İzlekleri, Ankara: Türksoy Yayınları.

Manas Entsiklopediya I, II. Tom (1995). Bişkek: Muras Yayını.

ORAL, Zeynep (1976); Cengiz Aytmatov ile Konuşma, Nesin Vakfı Yıllığı, İstanbul: N. V. Yayınları.

SAGINBEKOV, Bakıt İmanak (2007); “Cengiz Aytmatov'un 'Elveda Gülsarı' Eserinde Ana Motif Olarak At”, Ankara: I. Uluslararası Türk Dünyası Kültür Kurultayı-Bildiriler, Cilt IV.

ŞiŞMAN, Bekir (2007); "Cengiz Aytmatov'un "Elveda Gülsarı" Adlı Eserinde Kırgız Folkloruna Dair Tespitler" Ankara: I. Uluslararası Türk Dünyası Kültür Kurultay1- Bildiriler, Cilt V.

UZUN, Gülsine; Cengiz Aytmatov'un Eserlerinde Yaratılış ve Türeyiş Sembolizmi, Turkish Studies Türkoloji Araştırmaları Volume 2 / 2 Spring 2007. 


\section{AHMET SARIGÜL}

VELİHANOĞLU, Çokan; (http://gercektarihimiz.blogcu.com/tarihi-yonuylemanas-destani/4508911. 07. 03. 2016)

YILDIZ, Naciye (1998); Cengiz Aytmatov ve Manas Destanı, Doğumunun 70. Y1l Dönümünde Cengiz Aytmatov Uluslar Arası Bilgi Şöleni Bildirileri (8-10 Aralık), Ankara: Atatürk Kültür Merkezi Başkanlığı Yayınları. 